\title{
Influence of Integrated Nutrient Management on Growth Parameters, Yield and Severity of Disease in Onion (Allium cepa L.)
}

\author{
G. Ramesh $^{1}$, K. Ajithkumar ${ }^{2 *}$, Y.S. Amaresh ${ }^{3}$ and A.S. Savitha ${ }^{3}$ \\ ${ }^{1}$ Krishi Vigyana Kendra, ${ }^{2}$ Main Agriculture Research Station, ${ }^{3}$ Department of Plant Pathology, \\ University of Agricultural Sciences, Lingsugur Road, Raichur, Karnataka, India \\ *Corresponding author
}

\section{A B S T R A C T}

\section{Keywords}

Azospirillum, $P$. fluorescens, Purple blotch, Organic and inorganic fertilizers.

Article Info

Accepted: 14 June 2017 Available Online:

10 August 2017
Onion (Allium cepa L.) is an important vegetable crop grown extensively in Karnataka. A field experiment was conducted at Main Agricultural Research Station, University of Agricultural Sciences, Raichur, Karnataka during 2014 and 2015 to study the influence of organics, inorganic fertilizers, Azospirillum and Pseudomonas fluorescens on growth parameters, yield and purple blotch disease of onion. The experiment was laid out in randomized complete block design with 10 treatments and three replications. Significantly higher values were recorded for plant height $(62 \mathrm{~cm})$, number of leaves $(11.35)$, bulb diameter $(8.30 \mathrm{~cm})$, bulb weight $(57 \mathrm{~g})$ and total yield $(41.8 \mathrm{t} / \mathrm{ha})$ in the treatment consisting of 50 per cent of recommended nitrogen applied through poultry manure, 50 per cent nitrogen through inorganic fertilizers, Azospirillum and P. fluorescens but lower purple blotch severity $(22 \%)$ was recorded in the plots treated with 50 per cent recommended $\mathrm{N}$ through $\mathrm{FYM}+50$ per cent recommended $\mathrm{N}$ through inorganic fertilizers, Azospirillum and $P$. fluorescens. Control, recorded lower values for growth and yield parameters with higher purple blotch severity. Considering the results of this experiment, the conjunctive application of organic manure, inorganic fertilizers, Azospirillum and $P$. fluorescens was recommended to enhance the yield of onion.

\section{Introduction}

Onion is one of the important vegetable crops cultivated throughout the world. It is extensively used in many culinary preparations, therefore it commands a large internal market. Onion is preferred for its flavour and pungency which is attributed to the presence of volatile oil "allyl propyl disulphide". Onion bulb is a rich source of carbohydrates, protein, vitamin $\mathrm{C}$, phosphorus and calcium also possess good medicinal properties. Apart from its use in fresh form, onions are frozen or dehydrated. Dehydrated onion is in great demand as this reduces transport cost and storage losses. India is the second largest producer of onion in the world with an area of 11.73 lakh ha and production of 189.28 lakh tons next only to China with the productivity of 16.13 t/ha (Anonymous, 2016). Maharashtra is the leading onion growing state and other important states are Karnataka, Gujarat, Bihar, Madhya Pradesh, Andhra Pradesh, Rajasthan, Haryana, Uttar Pradesh and Tamil Nadu. Onion ranks first in the export of fresh vegetables from India constituting 73.94 per cent. In Karnataka onion is cultivated in an area of 1.87 lakh ha 
with a production of 322.70 lakh tons and productivity of 17.26 t/ha (Anonymous, 2016).

Nutrition is one of the most important factors which governs the onion production. Indiscriminate use of inorganic fertilizers in cultivation of onion has a deleterious effect on soil health. Hence, there is a need for supplementing the chemical fertilizers with organic manures.

The use of these organics results in higher growth, yield and quality of crops. The presence of organic matter improves soil physical properties, such as aggregation, increased soil aeration and lower bulk density, insisting surface crust, increased water retention and supply plant nutrients (Yafan and Barker, 2004).

Addition of organic manure to soil enhances microbial activity and increases their ability to conserve fertigation and consequently increasing their fertility and fertilizers use efficiency as a final goal (Nanwai et al., 1998). Organic manures, apart from improving physical and biological properties of soil, help in improving the use and efficiency of chemical fertilizers (Gedam et al., 2008).

FYM will improve the soil physical, chemical and biological properties along-with the provision of macro and micro nutrients (Augusti, 1996). Poultry manure has been reported to contain more plant nutrients than all other organic manures (Ali, 2005). Apart from being a general plant colonizer, Azospirillum also mineralize nutrients from the soil (Bashan et al., 2004).

Azospirillum brasilense can synthesize phenylacetic acid (PAA), an auxin like molecule with antimicrobial activity (Somers et al., 2005).
For healthy growth and optimal yield, nutrients must be available in correct quantity and in a usable form at right time. Ayoola and Adeniyan (2006) reported that nutrients from mineral fertilizers enhance the establishment of crops, while those from mineralization of organic manure promoted yield when both fertilizers were combined.

Use of organic manures in combination with chemical fertilizers in an appropriate proportion improves the soil health for sustainable production. Therefore, integrated nutrient management is a viable strategy for advocating judicious and efficient use of chemical fertilizers with matching addition of organic and biofertilizers.

\section{Materials and Methods}

This experiment was conducted in the field of sandy loam soil (PH 7.6) at University of Agricultural Sciences, Raichur. The experiment was comprised of 10 treatments that were replicated thrice each in a randomized block design with the plots measuring 5.4 x $3.5 \mathrm{~m}$.

\section{Application of fertilizers}

Recommended dose of fertilizers used in the experiment was $125 \mathrm{~kg} / \mathrm{ha} \mathrm{N}, 75 \mathrm{~kg} / \mathrm{ha} \mathrm{P}$ and $125 \mathrm{~kg} / \mathrm{ha} \mathrm{K}$. The fertilizers were applied as per the treatment plan.

\section{Application of organics}

Well decomposed farm yard manure $(0.5 \% \mathrm{~N}$, $0.5 \% \mathrm{P}$ and $0.5 \% \mathrm{~K}$ ) and poultry manure $(2.8 \% \mathrm{~N}, 1.5 \% \mathrm{P}$ and $1.2 \% \mathrm{~K})$ collected from the local market were applied to the soil in specific plots as per the treatments. Nursery bed was $(7.5 \mathrm{~m} \times 1.0 \mathrm{~m})$ prepared and Trichoderma treated (4g Trichoderma $/ \mathrm{kg}$ seed) onion seeds $(5 \mathrm{~kg} / \mathrm{ha})$ were sown. Seedlings at the age of 25-30 days were 
removed carefully from the nursery beds. Slurry of Azospirillum (1 kg) in water (5 l) was prepared and the seedlings removed from nursery beds were dipped in the slurry for a period of 30 minutes and then transplanted to the main plot.

Plots of size 5.4 × $3.5 \mathrm{~m}$ were prepared and the root dipped seedlings were transplanted in the main field at spacing of $15 \times 10 \mathrm{~cm}$. Foliar spray with $P$. fluorescens $(5 \mathrm{~g} / \mathrm{l})$ was given to the crop at 55 days after transplanting (DAT) in order to protect the crop from purple blotch disease.

Soil samples were collected from the rhizosphere region and subjected to Serial Dilution Plate Technique as suggested by Dobereiner et al., (1976) for determining viable counts of bacterial population of Azospirillum and total bacterial count.

Nitrogen free Walksman No 77 selective medium was used for estimation of population of Azospirillum and nutrient agar medium was used for estimation of total bacterial count.

\section{Data collection and statistical analysis}

Observations were recorded on the severity of purple blotch on leaves at 85 DAT by using disease index standard scale $0-5 \quad(0=$ no disease, $1=$ up to 10 per cent of leaf area with disease symptom, $2=11-25$ per cent disease; $3=26-50$ per cent; $4=51-75$ per cent disease and $5=>75$ per cent leaf area with disease symptom) and PDI was worked out as per the standard protocol (Sharma, 1986).

The experimental data was statistically analysed by Anova after the transformation of values. Observations were also recorded on plant height and number of leaves at 30, 60 and 90 DAT. Bulb diameter, bulb weight, plot yield and total yield were documented at harvest. Dry weight of the plant along with the bulbs was recorded after the complete harvest of the crop and the uptake of N, P and $\mathrm{K}$ by plants was estimated.

The available N (Subbaiah and Asija, 1956), $\mathrm{P}$ (Baker and Amacher, 1982) and K (Jackson, 1967) in the soil were also determined after complete harvest of the crop.

The pooled results were subjected to Fisher's method (Panse and Sukhatme, 1967) of analysis of variance (ANOVA) as applicable to Randomized Complete Block Design.

\section{Results and Discussion}

The growth parameters in onion are significantly influenced by the combined application of 50 per cent recommended $\mathrm{N}$ through poultry manure +50 per cent recommended $\mathrm{N}$ through inorganic fertilizers + Azospirillum + P. fluorescens (Table 1).

The combined application of poultry manure + inorganic fertilizers + Azospirillum increase the plant height and number of branches by 37.08 per cent and 9.66 per cent respectively with 23.67 per cent severity of purple blotch disease, over control followed by the application of 50 per cent recommended $\mathrm{N}$ through FYM + 50 per cent recommended $\mathrm{N}$ through inorganic fertilizers + Azospirillum + $P$. fluorescens in addition, minimum severity of purple blotch disease (22\%) is recorded.

The increase and uniform supply of nutrients at all the stages of plant growth could be due to the combined effect of poultry manure, inorganic fertilizers and Azospirillum. Poultry manure contains high percentage of nitrogen and phosphorous for healthy plant growth (Ewulo, 2005).

Poultry manure is not only a good source of nutrients, but also facilitates biological 
nitrogen fixation (Dosani et al., 1999). In addition to this Azospirillum could also have contributed to the improvement in growth related attributes because of certain growth promoting substance, secreted by it, besides increasing the availability of atmospheric nitrogen and soil phosphorus.

This might have led to better root and shoot development and better uptake of water and nutrients. Awodun (2007) reported similar results with the application of poultry manure on fluted pumpkin. Similar results were obtained by combined application of poultry manure and inorganic fertilizers on kalmegh (Ramesh et al., 2011) and onion (Muhammad et al., 2015).

The foliar application of $P$. fluorescens results in encouraging effect for the management of purple blotch. The results are in accordance with Savitha et al., (2014), they found that foliar spray of $P$. fluorescens gave significant management of purple blotch.

Because it acts as systemic resistance inducing agent by which it suppresses the growth and infection of the pathogen, in addition increased the vigour of the crop through PGPR effect.

The yield in onion is also influenced by the combined application of 50 per cent recommended $\mathrm{N}$ through poultry manure +50 per cent recommended $\mathrm{N}$ through inorganic fertilizers + Azospirillum $+P$. fluorescens (Table 1).

This combined application increased the bulb weight, bulb diameter, plot yield and total yield by $128,83.62,46.24$ and 36.13 per cent respectively, over control. Poultry manure has been reported to contain more plant nutrients than all other organic manures (Ali, 2005).
Oladotun (2002) reported that poultry manure contains macro and micro nutrients such as $\mathrm{N}$, $\mathrm{P}, \mathrm{K}, \mathrm{S}, \mathrm{Ca}, \mathrm{Mg}, \mathrm{Cu}, \mathrm{Mn}, \mathrm{Zn}, \mathrm{Bo}$ and $\mathrm{Fe}$, which increases the yield of crops. Poultry manure is a concentrated source of $\mathrm{N}$ and $\mathrm{P}$ (Dosani et al., 1999).

Beneficial effect of Azospirillum, may be due to nitrogen fixation and due to production of phyto-hormones like IAA, GA and cytokininlike substances, which stimulate the growth and induce changes in root morphology which in turn may influence assimilation of nutrients and better nutrient uptake (Srinivasan et al., 2005 and Sangeetha et al., 2008).

At higher level of organics, improved soil physical conditions might have resulted in better root growth, nutrient absorption and better bulb development. Similar results were recorded by Lal et al., (2002) who reported significant increase in bulb diameter and weight in onion.

Amanullah et al., (2007) reported that, application of increased levels of composted poultry manure increased the length and girth of the cassava tuber, which corroborate the findings of this study.

Similar results were documented by Adekiya and Agbede (2009) in tomato. The addition of NPK fertilizer to poultry manure might have aided mineralization of nutrients in poultry manure due to enhanced supply of nutrients.

Further addition of Azospirillum could have consistently and steadily supplied nutrients to the plants. Thus the treatment involving organic, inorganic fertilizers and Azospirillum contributed to the overall increase in yield.

Similar results were obtained by Bagali et al., (2012) in onion and Anand et al., (2015) in carrot. 
Table.1 Influence of integrated nutrient management on plant height, number of leaves, bulb weight, bulb diameter, plot yield, total Yield and severity of purple blotch in onion

\begin{tabular}{|c|c|c|c|c|c|c|}
\hline Treatments & $\begin{array}{c}\text { Plant } \\
\text { height }(\mathbf{c m})\end{array}$ & $\begin{array}{l}\text { Number } \\
\text { of leaves }\end{array}$ & $\begin{array}{c}\text { Bulb } \\
\text { weight (g) }\end{array}$ & $\begin{array}{c}\text { Bulb } \\
\text { diameter }(\mathbf{c m})\end{array}$ & $\begin{array}{l}\text { Total yield } \\
\text { (t/ha) }\end{array}$ & $\begin{array}{c}\text { Severity of purple } \\
\text { blotch }(\%)\end{array}$ \\
\hline $\mathrm{T}_{1}: 20 \mathrm{t} / \mathrm{haFYM}$ & 50.75 & 10.40 & 26.9 & 4.98 & 31.36 & $31.67(34.22)$ \\
\hline $\mathrm{T}_{2}: 5 \mathrm{t} /$ ha poultry manure & 53.00 & 10.54 & 30.8 & 5.79 & 33.97 & $30.67(33.62)$ \\
\hline $\mathrm{T}_{3}: 10 \mathrm{t} / \mathrm{ha} \mathrm{FYM}+2.5 \mathrm{t} / \mathrm{ha}$ poultry manure & 52.24 & 10.42 & 27.7 & 5.46 & 31.88 & $33.00(35.04)$ \\
\hline $\begin{array}{l}\mathrm{T}_{4}: 50 \% \text { recommended } \mathrm{N} \text { through } \mathrm{FYM}+ \\
50 \% \text { recommended } \mathrm{N} \text { through inorganic } \\
\text { fertilizers }+P . \text { fluorescens }\end{array}$ & 54.16 & 11.00 & 40.6 & 7.56 & 36.92 & $24.33(29.53)$ \\
\hline $\begin{array}{l}\mathrm{T}_{5}: 50 \% \text { recommended } \mathrm{N} \text { through poultry } \\
\text { manure }+50 \% \text { recommended } \mathrm{N} \text { through } \\
\text { inorganic fertilizers }+P . \text { fluorescens }\end{array}$ & 55.25 & 11.05 & 48.3 & 7.93 & 38.65 & $25.67(30.41)$ \\
\hline $\mathrm{T}_{6}: 100 \% \mathrm{~N}$ through inorganic fertilizers & 53.00 & 10.57 & 35.3 & 6.02 & 35.12 & $38.33(38.24)$ \\
\hline $\begin{array}{l}\mathrm{T}_{7}: 75 \% \mathrm{~N} \text { through inorganic fertilizers }+ \\
\text { Azospirillum }\end{array}$ & 53.21 & 10.82 & 38.0 & 6.45 & 36.45 & $37.33(37.64)$ \\
\hline $\begin{array}{l}\mathrm{T}_{8}: 50 \% \text { recommended } \mathrm{N} \text { through } \mathrm{FYM}+50 \\
\% \text { recommended } \mathrm{N} \text { through inorganic } \\
\text { fertilizers }+ \text { Azospirillum }+P . \text { fluorescens }\end{array}$ & 60.54 & 11.12 & 54.0 & 8.04 & 40.74 & $22.00(27.92)$ \\
\hline $\begin{array}{l}\mathrm{T}_{9}: 50 \% \text { recommended } \mathrm{N} \text { through poultry } \\
\text { manure }+50 \% \text { recommended } \mathrm{N} \text { through } \\
\text { inorganic fertilizers }+ \text { Azospirillum }+P \text {. } \\
\text { fluorescens }\end{array}$ & 62.10 & 11.35 & 57.0 & 8.30 & 41.89 & $23.67(29.10)$ \\
\hline $\mathrm{T}_{10}:$ Control (RDF) & 45.30 & 10.35 & 25.0 & 4.52 & 30.73 & $37.00(37.45)$ \\
\hline F Test & $*$ & $*$ & $*$ & $*$ & $*$ & \\
\hline SEM & 1.69 & 0.19 & 2.32 & 0.12 & 0.54 & 3.71 \\
\hline $\mathrm{CD}(\mathrm{P}=0.05)$ & 5.02 & 0.57 & 6.89 & 0.35 & 1.60 & 1.25 \\
\hline
\end{tabular}


Table.2 Influence of integrated nutrient management on uptake of nutrients by onion and available $\mathrm{N}, \mathrm{P}$ and $\mathrm{K}$ in the soil after the harvest of onion

\begin{tabular}{|c|c|c|c|c|c|c|}
\hline Treatments & $\begin{array}{c}\text { Available N } \\
\text { (kg/ha) }\end{array}$ & $\begin{array}{c}\text { Available P } \\
\text { (kg/ha) }\end{array}$ & $\begin{array}{c}\text { Available K } \\
\text { (kg/ha) }\end{array}$ & $\begin{array}{l}\text { N uptake } \\
\text { (kg/ha) }\end{array}$ & $\begin{array}{c}\text { P uptake } \\
\text { (kg/ha) }\end{array}$ & $\begin{array}{c}\text { K uptake } \\
\text { (kg/ha) }\end{array}$ \\
\hline $\mathrm{T}_{1}: 20 \mathrm{t} / \mathrm{ha} \mathrm{FYM}$ & 155.90 & 31.25 & 330.24 & 105.21 & 30.05 & 76.54 \\
\hline $\mathrm{T}_{2}: 5 \mathrm{t} /$ ha poultry manure & 160.31 & 33.18 & 343.68 & 119.34 & 31.00 & 81.54 \\
\hline $\mathrm{T}_{3}: 10 \mathrm{t} / \mathrm{ha} \mathrm{FYM}+2.5 \mathrm{t} / \mathrm{ha}$ poultry manure & 154.86 & 31.95 & 336.66 & 113.26 & 30.75 & 79.98 \\
\hline $\begin{array}{l}\mathrm{T}_{4}: 50 \% \text { recommended } \mathrm{N} \text { through } \mathrm{FYM}+50 \% \\
\text { recommended } \mathrm{N} \text { through inorganic fertilizers }+ \\
P . \text { fluorescens }\end{array}$ & 174.79 & 36.28 & 358.76 & 138.36 & 42.96 & 99.65 \\
\hline $\begin{array}{l}\mathrm{T}_{5}: 50 \% \text { recommended } \mathrm{N} \text { through poultry } \\
\text { manure }+50 \% \text { recommended } \mathrm{N} \text { through } \\
\text { inorganic fertilizers }+P . \text { fluorescens }\end{array}$ & 179.26 & 38.94 & 363.91 & 146.54 & 46.54 & 104.98 \\
\hline $\mathrm{T}_{6}: 100 \% \mathrm{~N}$ through inorganic fertilizers & 162.56 & 34.04 & 347.94 & 128.94 & 33.25 & 85.34 \\
\hline $\begin{array}{l}\mathrm{T}_{7}: 75 \% \mathrm{~N} \text { through inorganic fertilizers }+ \\
\text { Azospirillum }\end{array}$ & 165.98 & 34.56 & 355.94 & 131.65 & 36.58 & 91.68 \\
\hline $\begin{array}{l}\mathrm{T}_{8}: 50 \% \text { recommended } \mathrm{N} \text { through } \mathrm{FYM}+50 \% \\
\text { recommended } \mathrm{N} \text { through inorganic fertilizers }+ \\
\text { Azospirillum }+P . \text { fluorescens }\end{array}$ & 183.67 & 40.21 & 375.12 & 150.70 & 53.29 & 106.94 \\
\hline $\begin{array}{l}\mathrm{T}_{9}: 50 \% \text { recommended } \mathrm{N} \text { through poultry } \\
\text { manure }+50 \% \text { recommended } \mathrm{N} \text { through } \\
\text { inorganic fertilizers }+ \text { Azospirillum }+P \text {. } \\
\text { fluorescens }\end{array}$ & 190.53 & 43.85 & 380.54 & 158.56 & 56.34 & 110.53 \\
\hline $\mathrm{T}_{10}:$ Control (RDF) & 125.90 & 21.24 & 300.29 & 104.25 & 29.36 & 75.25 \\
\hline F Test & $*$ & $*$ & $*$ & $*$ & $*$ & $*$ \\
\hline SEM & 3.95 & 0.81 & 2.28 & 0.91 & 0.78 & 0.97 \\
\hline $\mathrm{CD}(\mathrm{P}=0.05)$ & 11.76 & 2.41 & 6.77 & 2.73 & 2.32 & 2.90 \\
\hline
\end{tabular}


Maximum population of Azospirillum (140 cfu/g soil x $\left.10^{4}\right)$ and total bacteria $(805 \mathrm{cfu} / \mathrm{g}$ soil $\left.\times 10^{4}\right)$ is observed in treatment T9 $(50 \%$ recommended $\mathrm{N}$ through poultry manure +50 $\%$ recommended $\mathrm{N}$ through inorganic fertilizers + Azospirillum $+P$. fluorescens) followed by the treatment T8 $(50 \%$ recommended $\mathrm{N}$ through farm yard manure + $50 \%$ recommended $\mathrm{N}$ through inorganic fertilizers + Azospirillum $+P$. fluorescens). However, the treatments that receive poultry manure also had significantly higher population of Azospirillum and total bacteria.

The uptake of nitrogen (158.56 kg/ha), phosphorous $(56.34 \mathrm{~kg} / \mathrm{ha})$ and potassium $(110.53 \mathrm{~kg} / \mathrm{ha})$ was maximum in T9 $(50 \%$ recommended $\mathrm{N}$ through poultry manure +50 $\%$ recommended $\mathrm{N}$ through inorganic fertilizers + Azospirillum $+P$. fluorescens) . Lower N, P and $\mathrm{K}$ uptake was observed in control. The available NPK in soil after harvest was high in T9 (Table 2). This could be due to the conjunctive use of organic manure and inorganic fertilizers which helped in the build-up of active pools of NPK and maintained their regular supply for proper plant growth and yield. Increase in nitrogen uptake could be due to the breakdown of complex nitrogenous compounds to nitrate nitrogen due to action of microorganisms. Increase in $\mathrm{P}$ could be due to greater solubilization of native $\mathrm{P}$ from the soil due to action of various organic acids liberated due to decomposition of organics. Increased $\mathrm{K}$ uptake could be ascribed to the improved soil properties due to the action of organics, leading to better penetration of roots, thereby resulting to greater uptake of K. Similar results on conjunctive application of both organic and inorganic fertilizers were documented by Ramesh et al., (2011) in kalmegh.

From the present study it can be concludes that the combined application of organics, inorganic fertilizers and biofertilizers along with foliar application of $P$. fluorescens produce better growth and yield parameters with effective management of purple blotch disease.

\section{References}

Adekiya, A. O. and Agbede, T. M., 2009. Growth and yield of tomato (Lycopersicon esculentum Mill.) as influenced by poultry manure and NPK fertilizer. Emir. J. Food Agric., 21 (1): 10-20.

Ali, G. A., 2005. Uses of manure and fertilizer as soil management technique for sustainable crop production. Paper presented at a workshop organized by Taraba State Local Government Service Commission on $8^{\text {th }}$ and $9^{\text {th }}$, December 2005.

Amanullah, M. M., E. Somasundaram, K. Vaiyapuri and Alagrsan, A., 2007. Influence of fertilizers and organic manures on the yield attributes and yield of cassava (Manihot esculenta Crantz.). Int. J. Agric. Sci., 3 (1): 205208.

Anand, G. P., A. R. M. Sayeed, and Mohammed, F. 2015. Integrated nutrient management in carrot (Daucus carrot L.) under North Eastern transitional track of Karnataka. Res. J. Agril. Sci., 6 (3): 571-572.

Anonymous, 2016. Annual Report, Directorate of Onion and Garlic Research, ICAR Rajgurunagar, Pune.

Augusti, K., 1996. Therapeutic values of onion and effect of organic and inorganic fertilizers on garlic. Ind. $J$. Exp. Bio., 34(7): 634-640.

Awodun, M. A., 2007. Effect of poultry manure on growth, yield and nutrient content of fluted pumpkin (Telfaria occidentalis Hook F.). Asian J. Agril. Res., 1: 67-73. 
Ayoola, O. T. and Adeniyan, O. N., 2006. Influence of poultry manure and NPK fertilizer on yield and yield components of crops under different cropping systems in south west Nigeria. African J. Biotech., 5 (15): 1386- 1392.

Bagali, A. N., H. B. Patil, P. Chimmad, P. L. Patil and Patil, R. V., 2012. Effect of inorganics and organics on growth and yield of onion (Allium cepa L.). Karnataka J. Agric. Sci., 25 (1): 112115.

Baker, D. E. and Amacher, M. S., 1982. Nickel, copper, zinc and cadmium. In methods of soil analysis. Agronomy Monograph, 9: 323-326.

Bashan, Y., G. Holguin and de-Bashan, L. E., 2004. Azospirillum-plant relationships: physiological, molecular, agricultural, and environmental advances (19972003). Canadian J. Microbiology, 50: 521-577

Dobereiner, J. and Day, D. M., 1976. Associative symbiosis in tropical grasses. Charecterization of microorganisms and di-nitrogen fixing sites. pp. 518-536. In Newton, E., Nymen, C. J. (ed) Proc: First International Symposium on Nitrogen Fixation. Washington State University Press.Pullman.

Dosani, A. A. K., S. Talashikar and Mehta, V. B., 1999. Effect of poultry manure applied in combination with fertilizers on the yield, quality and nutrient uptake of groundnut. J. Indian Soc. Soil. Sci, 47: 166-169.

Ewulo, B. S., 2005. Effect of poultry manure and cattle manure on sandy clay loam soil. J. Anim. Vet. Sci., 4: 839 - 841 .

Gedam, V. B., J. R. Rametke, Rudragouda and Power, M. S., 2008. Influence of organic manures on yield, nutrient uptake of groundnut and change in physic-chemical properties of soil after harvest of groundnut. Crop Res. 36 (1, 2 \& 3): 111-114.

Jackson, M. L., 1967, Soil chemical analysis, Prentice Hall of India Pvt. Ltd., New Delhi.

Lal, S., A. C. Yadav, J. L. Mangal, Avtar Singh and Batra, V. K., 2002. Effects of FYM and irrigation levels on growth and yield of onion cv. Hisar-2. Haryana J. Hort. Sci., 31(3-4): 256-258.

Muhammad, F., H. S. Azhar, A. M. Ahmad, A. Niaz, K. Uzma, M. Abdul, A. Habib and Natarajan, K., 2015. Nutrient management for improving onion productivity. American-Eurasian $J$. Agric. Environ. Sci., 15 (2): 220-225,

Nanwai, R. K., B. D. Sharma, and Taneja, K. D., 1998. Role of organic and inorganic fertilizers for maximizing wheat Triticum aestivum yield in sandy loam soils. Crop Research, 16(2): 159-161.

Oladotun, A. O., 2002. Managing manure as a fertilizer; Saskatchewani, Agriculture, Food and Rural Revitalization. 5 pp.

Panse, V. G. and Sukhatme, P. V., 1967. Statistical Methods for Agricultural Workers, ICAR, New Delhi, PP: 381.

Ramesh, G., M. B. Shivanna and Santa Ram, A., 2011. Interactive influence of organic manures and inorganic fertilizers on growth and yield of kalmegh. (Andrographis paniculata Nees.). Interl. Res. J. Pl. Sci., 2 (1): 016-021.

Sangeeth, K. P., R. Susheelabhai and Srinivasan, V., 2008. Evaluation of indigenous Azospirillum isolates for growth promotion in black pepper (Piper nigrum L.) rooted cuttings. $J$. Spices Arom. Crops, 11: 128-33.

Savitha, A. S., K. Ajithkumar and Ramesh, G., 2014. Integrated disease management of purple blotch [Alternaria porri (Ellis) Cif] of onion, Pest Manage. Horti. Ecosystems, 20 (1): 97-99. 
Sharma, S. R., 1986. Effect of fungicidal sprays on purple blotch and bulb yield of onion. Indian Phytopath, 39: 78-82.

Somers, E., D. Ptacek, P. Gysegom, M. Srinivasan and Vanderleyden, J., 2005. Azospirillum brasilense produces the auxin-like phenylacetic acid by using the key enzyme for indole-3-acetic acid biosynthesis. Applied and Environmental Microbiology, 71: 18031810.

Srinivasan, V., S. Hamza and Sadanandan, A. K., 2005. Evaluation of composted coir pith with chemical and bio-fertilizers on nutrient availability, yield and quality of black pepper (Piper nigrum L.). $J$. Spices Arom. Crops, 14: 15-20.

Subbaiah, B. V. and Asija, G. L., 1956. A rapid procedure for estimation of available nitrogen in soil. Curr Sci, 37: 171-173.

Yafan, H. and Barker, A. V., 2004. Effect of composts and their combinations with other materials and their combinations with other materials on nutrient accumulation in tomato leaves. Communications in Soil Science and Plant Analysis, 35 (19-20): 2809 2823.

\section{How to cite this article:}

Ramesh, G., K. Ajithkumar, Y.S. Amaresh and Savitha, A.S. 2017. Influence of Integrated Nutrient Management on Growth Parameters, Yield and Severity of Disease in Onion (Allium Cepa L.). Int.J.Curr.Microbiol.App.Sci. 6(8): 1020-1028. doi: https://doi.org/10.20546/ijcmas.2017.608.126 